\title{
Pengaruh Metode Demonstrasi Menggunakan Alat Sederhana Terhadap Penguasaan Konsep Siswa Tentang Hukum III Newton pada Kelas X SMA Negeri 1 Sindue
}

\author{
Lilis Karlina, Jusman Mansyur dan Nurjannah \\ email : Liliskarina74@yahoo.co.id \\ Program Studi Pendidikan Fisika FKIP Universitas Tadulako \\ Jl. Soekarno Hatta Km. 9 Kampus Bumi Tadulako Tondo Palu - Sulawesi Tengah
}

Penelitian ini bertujuan untuk mengetahui ada tidaknya pengaruh metode demonstrasi menggunakan alat sederhana terhadap penguasaan konsep siswa tentang Hukum III Newton di SMA Negeri 1 Sindue. Jenis penelitian yang digunakan adalah kuasi eksperimen dengan desain "The non equivalen pretestposttest design". Sampel dipilih menggunakan teknik purposive sampling dan menghasilkan kelas X Mia 4 sebagai kelas eksperimen dan kelas X Mia 3 sebagai kelas kontrol. Instrumen yang digunakan berupa tes penguasaan konsep dalam bentuk pilihan ganda. Analisis data tes dilakukan dengan teknik statistik uji-t satu pihak untuk menguji peningkatan hasil tes penguasaan konsep siswa. Berdasarkan analisis data, dapat disimpulkan bahwa terdapat pengaruh metode demonstrasi menggunakan alat sederhana terhadap penguasaan konsep siswa.

Kata kunci : Metode Demonstrasi, Penguasaan Konsep

\section{PENDAHULUAN}

Ilmu Fisika merupakan bagian dari mata pelajaran sains yang menuntut siswa untuk berinteraksi langsung dengan sumber belajar, tidak hanya memahami konsep ilmu pengetahuan saja, namun perlu penggabungan pengalaman melalui serangkaian kegiatan pembelajaran sebagai langkah-langkah menuju penguasaan konsep. Penguasaan konsep adalah cara untuk mendalami benar tentang ide yang terkandung dalam suatu bahan. Cara untuk mendalami dengan benar menunjukkan suatu kemampuan dimana kemampuan tersebut dapat di perlihatkan dengan jalan menerjemahkan bahan tersebut dengan suatu bentuk ke bentuk lain. Proses penguasaan konsep fisika akan lebih bermakna bagi siswa jika konsep, fakta-fakta maupun prinsip-prinsip fisika dapat dikaitkan dengan konsep relevan yang terdapat dalam struktur kognitif siswa, sehingga dapat menguasai konsep fisika secara benar $^{[1]}$.

Beberapa penelitian yang relevan dengan penelitian ini antara lain sebagai berikut :

Roestiyah (1991) metode demonstrasi adalah cara mengajar seorang instruktur atau guru dengan memperlihatkan suatu proses sehingga seluruh siswa dalam kelas dapat melihat, mengamati, dan mendengar. Metode demonstrasi cara penyajian guru untuk memperagakan atau presentasi menunjukkan suatu prosedur yang harus dilakukan peserta didik yang tidak dapat dijelaskan hanya dengan kata-kata saja. ${ }^{[2]}$

Djamara (2002) metode demonstrasi diartikan sebagai cara penyajian pelajaran dengan memperagakan dan mempertunjukkan kepada peserta didik suatu proses, situasi atau benda tertentu yang sedang di pelajari baik di dalam bentuk sebenarnya maupun dalam bentuk tiruan yang dipertunjukkan oleh guru atau sumber belajar lain yang memahami atau ahli dalam topik bahasan yang harus di demonstrasikan. ${ }^{[3]}$

Dahar (1996) penguasaan konsep diperoleh melalui proses belajar sedangkan belajar merupakan proses kognitif yang melibatkan tiga proses yaitu memperoleh informasi baru, mentransformasikan informasi dan menguji relevansi dan ketetapan pengetahuan, proses tersebut berlangsung secara bersamaan. ${ }^{[4]}$

Buzan (2009) mengatakan bahwa untuk melatih keterampilan berpikir kreatif maka diperlukan lingkungan yang kreatif. Melakukan demonstrasi dengan menggunakan alat sederhana dapat membiasakan siswa untuk tidak terjebak dengan permasalahan yang ada dan dapat menciptakan lingkungan yang kreatif bagi siswa sehingga diharapkan dengan menggunakan alat sederhana dan dapat 
menambah penguasaan konsep siswa

\section{METODE PENELITIAN}

Jenis penelitian yang digunakan dalam penelitian ini yaitu eksperimen semu (quasi experiment.

Desain yang digunakan dalam penelitian ini adalah "The non equivalen pretest-posttest design" atau rancangan pretest-posttest yang tidak ekuivalen yaitu menggunakan kelas yang sudah ada sebagai kelompoknya, dengan memilih kelas-kelas yang sudah ada diperkirakan sama keadaan/kondisinya. Bentuk desainnya disajikan pada Tabel 3.1.

Tabel 1 Desain penelitian

\begin{tabular}{|c|c|c|c|}
\hline Kelas & $\begin{array}{c}\text { Tes } \\
\text { Awal }\end{array}$ & Perlakuan & $\begin{array}{c}\text { Tes } \\
\text { Akhir }\end{array}$ \\
\hline A (Eksperimen) & $\mathrm{O}$ & $\mathrm{X}$ & $\mathrm{O}$ \\
$\mathrm{B}$ (Kontrol) & $\mathrm{O}$ & - & $\mathrm{O}$ \\
\hline
\end{tabular}

Keterangan :

A : Kelas eksperimen

$B$ : Kelas kontrol

O : Tes awal / Tes akhir

$X$ : Metode demonstrasi menggunakan alat sederhana.

Penelitian ini dilaksanakan di SMA Negeri 1 Sindue. Penelitian ini dilaksanakan mulai tanggal 02 September hingga tanggal 17 September 2014.

Populasi dalam penelitian adalah seluruh siswa kelas $X$ SMA Negeri 1 Sindue Tahun ajaran 2014-2015 yang terdiri dari 2 kelas. Sampel dari penelitian ini adalah sebagian dari siswa kelas X SMA Negeri 1 Sindue yaitu kelas $X$ MIA 4 sebagai kelas eksperimen dan kelas $X$ MIA 3 sebagai kelas kontrol. Penarikan sampel pada penelitian ini ditentukan dengan menggunakan teknik purposive sampling atau penentuan sampel dengan pertimbangan tertentu.

\section{HASIL DAN PEMBAHASAN}

Dalam penelitian ini instrumen yang digunakan berupa tes penguasaan konsep yang terdiri dari 15 soal pretest dan 20 soal posttest dalam bentuk pilihan ganda. Setiap item soal tes telah divalidasi oleh validator ahli.

Setelah dilakukan perhitungan tes penguasaan konsep untuk kelas eksperimen dan kelas kontrol baik pretest maupun posttest diperoleh data hasil penelitian seperti pada tabel 4.1
Tabel 2 Hasil pretest dan posttest tes penguasaan konsep.

\begin{tabular}{|l|c|c|c|c|}
\hline \multirow{2}{*}{ Uraian } & \multicolumn{2}{|c|}{ Pretest } & \multicolumn{2}{c|}{ Posttest } \\
\cline { 2 - 5 } & Eksperimen & Kontrol & Eksperimen & Kontrol \\
\hline $\begin{array}{l}\text { Skor } \\
\text { Terendah }\end{array}$ & 6,00 & 6,00 & 15,00 & 10,00 \\
\hline $\begin{array}{l}\text { Skor } \\
\text { Tertinggi }\end{array}$ & 66,00 & 60,00 & 60,00 & 55,00 \\
\hline $\begin{array}{l}\text { Skor } \\
\text { Rata-rata }\end{array}$ & 27,79 & 26,10 & 33,57 & 26,17 \\
\hline
\end{tabular}

Berdasarkan hasil analisis kualitatif pemberian tes awal (pretes) yang sesuai tabel 4.1 diperoleh skor rata-rata dari masing-masing kelas adalah 27,79 untuk kelas eksperimen dan 26,10 untuk kelas control. Hasil ini menunjukkan adanya perbedaan skor antara kedua kelas, dimana terlihat skor untuk kelas eksperimen lebih tinggi dibandingkan kelas control. Selanjutnya untuk kemampuan siswa dari pemberian tes akhir (posttes) diperoleh nilai rata-rata dari masing-masing kelas adalah 33,57 untuk kelas eksperimen dan 26,17 untuk kelas control.

Pada saat dilakukan posttes diperoleh rata-rata seperti pada tabel 4.1 yaitu untuk kelas eksperimen sebesar 33,57 dengan $\mathrm{N}$-gain $42,62 \%$ dan kelas control sebesar 26,17 dengan $\mathrm{N}$-gain sebesar $28,98 \%$. Hasil tersebut menunjukkan bahwa kelas eksperimen yang menerima materi dengan metode demonstrasi menggunakan alat sederhana memperoleh peningkatan penguasaan konsep lebih tinggi dari pada kelas control yang menerima materi dengan model konvensional namun demikian skor $\mathrm{N}$-gain kedua kelas tersebut masih termasuk dalam kategori sedang.

Berdasarkan uji-t yang dilakukan diperoleh hasil untuk thitung sebesar 3,00 sedangkan $t_{\text {tabel }} 1,67$. Nilai $t_{\text {hitung }}>t_{\text {tabel }}$ dengan demikian $\mathrm{H}_{1}$ diterima, artinya terdapat pengaruh metode demonstrasi menggunakan alat sederhana terhadap penguasaan konsep antara kelompok siswa yang mengikuti metode demonstrasi menggunakan alat sederhana dengan model konvensional.

Walaupun demikian masih ada beberapa konsep yang belum dikuasai oleh siswa, seperti soal pada materi Hukum III newton yaitu: "mengapa pada saat memukul tembok, tangan anda merasa sakit?" Jawaban siswa bervariasi, ada yang menjawab tembok sangat keras, ada juga yang menjawab terdapat reaksi dari tembok, dari jawaban siswa tersebut masih kurang lengkap. Jawaban yang tepat untuk pertanyaan ini adalah Karena, pada saat kita memukul tembok, kita memberikan gaya aksi ke tembok. Kemudian, tembok memberikan gaya reaksi kepada tangan kita dengan gaya yang sama besar dan berlawanan arah. Adapun 
soal berikutnya "Ketika Yani dan temannya sedang bermain sepatu roda sambil berhadapan, kemudian doronglah temanmu itu secara perlahan tanpa melepaskan pegangan. Apa yang terjadi?" Banyak jawaban siswa yang muncul, ada yang menjawab yani dan temannya akan sama-sama terdorong kebelakang, sebagian siswa menjawab salah satu dari mereka terjatuh, dari semua jawaban yang diberikan oleh siswa kurang tepat. Jawaban yang tepat adalah karena Yani memberikan gaya dorong pada temannya, maka temannya juga akan memberikan gaya terhadap Yani yang besarnya sama dengan arah yang berlawanan.

Kelebihan dari metode demonstrasi yang didapatkan oleh peneliti saat melakukan proses pembelajaran yaitu siswa aktif mengikuti pembelajaran, siswa mudah memahami materi, proses pengajaran lebih menarik.

Adapun hambatan dalam pelaksanaan pembelajaran menggunakan metode demonstrasi. Pada pertemuan pertama siswasiswa terlihat bingung. Ketika ditanyakan apa permasalahannya, barulah mereka menjelaskan bahwa mereka masih bingung membedakan aksi dan reaksi dari Hukum III Newton. Hal ini sesuai dengan pendapat Gonzales dkk (2007), bahwa siswa mengalami kesulitan dalam belajar fisika dengan nilai yang rendah perlu diberikan pembelajaran yang lebih membuat para siswa memahami apa yang dipelajari dengan melakukan praktek secara langsung dengan bimbingan dari guru.

Berdasarkan penelitian ini bahwa peningkatan penguasaan konsep siswa pada kelas eksperimen lebih bagus dibandingkan dengan kelas kontrol berdasarkan hasil uji $\mathrm{N}$ gain dan uji hipotesis.

\section{KESIMPULAN}

Berdasarkan hasil penelitian dan analisis data maka dapat disimpulkan bahwa terdapat pengaruh metode demonstrasi menggunakan alat sederhana terhadap penguasaan konsep. Pada kelas yang diteliti penguasaan konsep mengalami peningkatan dan berada dalam katagori sedang.

\section{DAFTAR PUSTAKA}

[1] Slameto (1995). Belajar dan Faktor-Faktor yang Mempengaruhinya. PT. Rineka Cipta. Jakarta.

[2] Roestiyah (1991). Strategi Belajar dan Pembelajaran. P.T Rineka Cipta, Jakarta.
[3] Djamara (2002). Psikologi Belajar. PT Rineka Cipta : Jakarta.

[4] Dahar, R.W (1996). Teori-Teori Belajar. Jakarta: Erlangga.

[5] Buzan (2008). Mind Map. Jakarta: Gramedia Pustaka Utama.

[6] Nopa (2012). Penerapan Metode Demonstrasi untuk Meremediasi Miskonsepsi siswa pada materi Hukum Newton di SMP. FKIP UNTAN.

[7] Lutfi (2012). Pembuatan dan Implementasi Modul Praktikum Fisika Berbasis Masalah Untuk Meningkatkan Kemandirian Belajar Siswa Kelas XI. Universitas Negeri Semarang. 1, (2), 39-40. 